\title{
Pabaigos teorijos mados ir meno diskurse
}

\section{Liucija Kvašytè}

Vilniaus dailès akademija, Doktorantūros katedra

Maironio g. 6, LT-01124 Vilnius

liucija.kvasyte@gmail.com

—_ Šiame straipsnyje siekiama ịvardyti, kodèl svarbu skirstyti mados egzistavimą i etapus ir net pabaigas? Apžvelgiama, kaip nuo $1774 \mathrm{~m}$. iki šių dienų keitėsi rūbo statusas ir kaip visuomenė prièmė mados pakilimus bei nuosmukius. Analizuojant mados chronologiją ir mados tyrèjų iškeltą mados pabaigos teoriją, aptariamas mados vystymasis ir dvi jos pabaigos: pirmoji, įvardyta mados istorikès Valerie Steele, sutampa su filosofo Arthuro Colemano Danto teorijos chronologija, tuo tarpu antroji mados pabaiga, apie kurią kalba sociologè Patrizia Calefato, vyksta šiandien greitosios mados vartojimo ịsuktame pasaulyje. Šiuo tekstu siekiama išsiaiškinti, kuo mums yra svarbios pabaigos teorijos ir kodèl apie tai reikètų kalbèti šiandieninès mados kontekste?

Reikšminiai žodžiai: mados pabaiga, meno pabaiga, fast fashion, kostiumo istorija. 


\section{Rūbo „mirtis" šiandieninès mados sampratoje}

Žodžio „mada“ kilmè susijusi su lotynišku žodžiu modus, reiškiančiu „būdą, saiką, taisyklę, nurodymą, matą“"1 leidžiančiu veikti mados sistemai pagal aiškią struktūrą, tačiau nuolat balansuojant tarp populiaraus sprendimo ir unikalumo ${ }^{2}$. Rūbai tampa mada, kai juos tokiais esant patvirtina šios srities profesionalai, todèl, viena vertus, mada yra skirta masėms, tačiau jai yra būdingas ir elitizmas. Pavyzdžiui, baroko laikotarpiu mados taisykles diktavo dvarų aukštuomenè, o šiandien ši vaidmenị yra prisièmę dizaineriai arba aktyvūs mados vartotojai. Mados istorikai ir tyrèjai rūbo egzistavimą iš šiandieninès perspektyvos skirsto ị keturis periodus: 1) kostiumo istorija (nuo antikos iki 1860 m.); 2) Haute Couture (pranc. aukštoji mada), arba auksinis Paryžiaus Haute Couture amžius (1860-1960); 3) Prêt-à-porter (pranc. paruošta dėvėti) (1960-1990); 4) Fast Fashion (greitoji mada) (nuo 1990 m. iki dabar). Šiandien egzistuoja trys pastarosios rūbo, kaip mados objekto, kryptys, kurių gaminamuose objektuose neretai jaučiama kostiumo istorijos, kaip pagrindinės inspiracijos, ittaka. Aukštoji mada išliko sunkiai prieinama, meistrystę ir talentą demonstruojanti meninès mados kryptis, kurios objektus dažniausiai aptinkame muziejuose, ant podiumo arba apdovanojimų scenose. Prêt-à-porter orientuota ì masinę gamybą pagal standartizuotą dydžių skalę, o jos atšaka - greitoji mada atlieka vartotojo patenkinimo funkciją. Jos išpopuliarèjimas sutapo su globalizacija, nes tuo metu pradèti kopijuoti didžiajai visuomenès daliai finansiškai sunkiau prieinami mados objektai, o dèl spartumo smuko gaminių kokybė ir moralinė vertè. Todėl šiandien ypač juntamas nuolatinis mados varijavimas tarp imitacijos ir inovacijos, kai žmogus siekia individualumo, laikydamas save išskirtiniu, tačiau tuo pačiu ieško socialinès grupès, prie kurios prisišliejęs tampa jos dalimi ir taip paneigia savo unikalumą. İvairūs mados mechanizmai išmokè vartotoją per prekę igyti tariamą ịvaizdị, statusą arba net gyvenimo būdą. Kaip pastebi prancūzų sociologas ir filosofas Jeanas Baudrillard'as, vartotojo ryšys su objektu jau pasikeitęs - svarbus ne dèl jo specifinès naudos, o dèl visuotinai priimtos reikšmès: drabužiai, aparatai, tualeto reikmenys sudaro objektų grandines, kurios vartotojui sukelia inertišką îtampą - jis pagal loginę seką

1 https:/latin-dictionary.net/definition/27114/modus-modi.

2 Otto von Busch, „The game of fashion and lookbook.nu“, in Sandy Black, The Sustainable Fashion Handbook (London: Thames \& Hudson, 2012), 17. 
keliauja nuo vieno objekto prie kito, yra ịtraukiamas ị objektų išskaičiavimą, ị tai, kas visiškai skiriasi nuo pirkimo svaigulio ir nuosavybės jausmo, kylančių dèl pačios prekių gausos ${ }^{3}$.

Pasiteisinęs tokios sistemos veikimas leido mados sektoriui sukurti sistemą, generuojančią naujas pradžias, pasibaigiančias liūdinančiu „,nebemadinga“, ir iš to kylančias pabaigas. Egzistuojanti mados ir rūbo „mirtis“ turi dvi kryptis - fizinę ir moralinę. Fizinè reiškia rūbo nusidèvẻjimą, jam prarandant utilitarines funkcijas, tuo tarpu moralinè grịsta psichologiniu prisirišimu prie daikto arba jị ịprasminančių mados tendencijų. Dèl mados pramonès suprojektuoto greičio ir nuolatinio kismo rūbas tampa pigesnis, prieinamesnis, tuo pačiu ir moraliai nuvertėjęs. Karantino metu, sumažèjus demonstratyvaus vartojimo situacijoms, turëjome progą pažvelgti ị savo nenaudojamus rūbus - aš pati suvokiau, kad daugelis jų nẻra niekuo ypatingi, tačiau tokiais tampa tik devètojo dèka. Todèl šiandien, rūbui vis labiau prarandant moralinę vertę, svarbu ịsigilinti ị jo identitetą dèl jo paties, vertinant ji per jo estetines ir utilitarines savybes, o ne kai jis dèvimas.

Masinės mados rūbą dažniausiai matome parduotuvės arba namų aplinkoje - tvarkingai sulankstytą lentynoje arba pakabintą ant pakabos, aprengtą ant manekeno ar žmogaus kūno. Šie atvejai atkrenta kaip rūbo veikimas pagal jam sukurtą scenarijų. Mane, kaip dizaino tyrëją, kaip tik domina gatvėje ar namuose chaotiškai sumesti rūbų kūnai, apie kurių rūši ar paskirti galime nuspręsti tik iš bendro suvokimo arba iš prieš tai egzistavusio tiesioginio santykio su jais [1-3 il.]. 2013 m. Bangladeše įvykusi rūbų fabriko „Rana Plaza“ griūtis buvo vienas pirmụjų ženklų visam mados sektoriui, ypač greitosios mados pramonei, apie jų praktikuojamą neetišką ir netvarią gamybą. Nuotraukos ir vaizdo ịrašai iš nelaimès vietos atskleidè mados ženklus, kurie naudojosi amoralia fabriko gamyba, tarp griuvėsiu matosi besimètantys rūbai ir etiketès, po visą teritoriją išsitampę audinių rulonai, kurie tapo gelbèjimosi lynais ieškantiesiems po griuvėsiais palaidotų artimujų [4 il.]. Tokie vaizdiniai man siejasi su vakarietiškų greitosios mados parduotuvių, išpardavimų metu tampančių kovos lauku, vaizdiniais ir primena protestus, kurie baigiasi išdaužytu parduotuvių vitrinomis ir nusiaubtais prekybos centrais [5, 6 il.]. Taigi rūbui tapus svarbiu socialiniu

3 Jean Baudrillard, Vartotoju visuomene: mitai ir struktūros, iš prancūzų kalbos vertè Neringa Abrutytė (Kaunas: Kitos knygos, 2010), 17. 


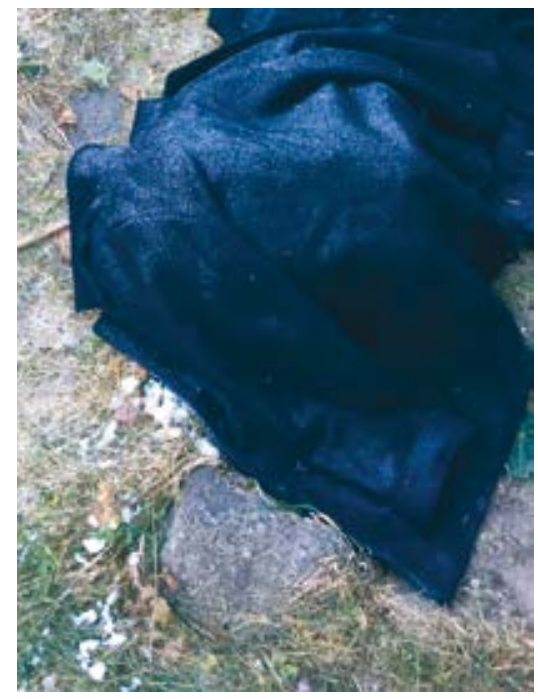

1.

Rūbo egzistavimas nenumatytame veikimo scenarijuje: saugant nuo šalnu, paltu apklotos piliarožès, Liucijos Kvašytės nuotrauka, 2020

Existence of clothing outside the intended operating scenario: tflowers are covered with a coat to protect them from cold during the winter, photo by Liucija Kvašytè, 2020

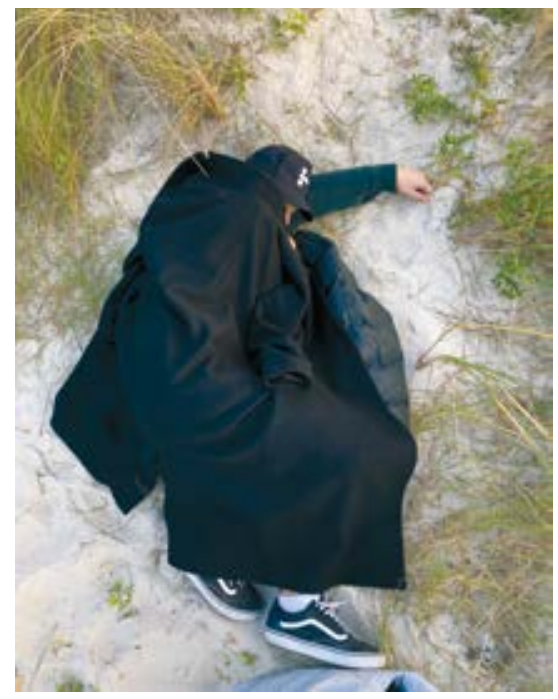

2.

Rūbų egzistavimas nenumatytame veikimo scenarijuje: paltas kaip apklotas miegančiam žmogui, Liucijos Kvašytės nuotrauka, 2020

Existence of clothing outside the intended operating scenario: a coat serving as a blanket for a sleeping person, photo by Liucija Kvašytė, 2020

klausimų objektu, neišvengiamai prieiname prie klausimo, kokia yra mados ateitis ir kaip šiandien mes, kaip vartotojai, kaip įstatymų leidejjams įtaką darantys piliečiai arba kaip kūrejjai, galime ją formuoti? Man, kaip vartotojai ir mados dizainerei, svarbu suvokti tikrajj, o ne pramonès primestą mados ciklą, kai rūbas iggyjamas ne iš poreikio ir nurašomas ne dèl utilitarinių funkcijų praradimo. Tuo atsiskleidžia naujos rūbo vertès: trumpalaikiškumas, plagijarizmas, spekuliatyvumas, banalumas, permainingumas ir išliekamosios vertės nebuvimas. Panašu, kad senieji mados dizaino principai nebeatitinka prie greitosios mados tempo pripratusio vartotojo lūkesčių. Tačiau ar šioje situacijoje reikètų kaltinti vartotoją ar sistemą?

Pabaigos teorijos beveik visais atvejais yra susijusios su kapitalizmo progresyvumu ir technologijų tobulëjimu, nors tai ypač būdinga rūbų mados pramonei, apie pabaigas mados lauke negirdime. Itprastai galètume 


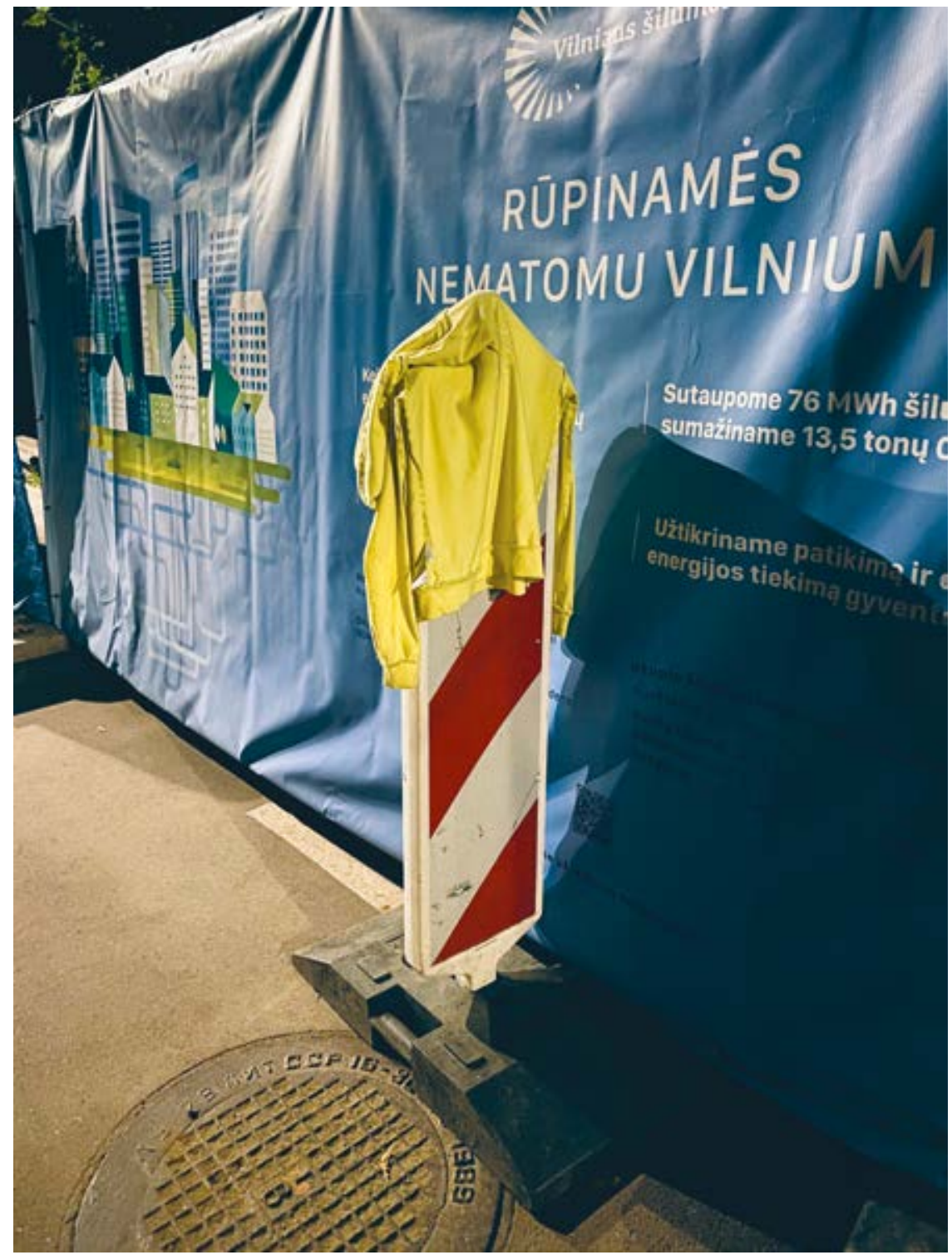

3.

Rūbų egzistavimas nenumatytame veikimo scenarijuje: pamestas džemperis vienoje Vilniaus gatviu, Liucijos Kvašytès nuotrauka, 2020
Existence of clothing outside the intended operating scenario: a sweater lost in one of the streets of Vilnius photo by Liucija Kvašytė, 2020 
isivaizduoti, kad numatomos ar esamos pabaigos leidžia permąstyti veikimo procesus, atsinaujinti, rasti tinkamus sprendimus tobulèti. Tačiau mada, rodos, egzistuoja ir veši pagal visai kitas taisykles. Manipuliatyvi rūbų mados rinkodara sukūrẻ kitą sistemą, neturinčią analogų ir veikiančią jau per 200 metų. Jos neracionalumas, pokyčiai vardan pokyčių aiškiai atsiskleidžia skatinant vartoti dèl vartojimo ir per prekes kurti nuolat atsinaujinanti ir niekada nenumalšinamą vartojimo alkị. Kaip teigia filosofas George'as Simmelis: „Mada neturi jokio galutinio tikslo - ji niekur nedings, tik eis i prieki.““ Tokiam „kūrybiniam“ mechanizmui palaikyti mada taupo savuosius resursus, nuolat atkartodama jau matytus siluetus, spalvinius derinius, proporcijas. Mados tyrèjai teigia, kad tendencijos kartojasi dèl besikeičiančios dizainerių kartos, kuri semiasi ịkvèpimo iš savo pačiu tėvų jaunystės garderobo. Egzistuojantys penki mados ciklo etapai - izžanga, kilimas, pikas, nuosmukis ir išèjimas iš mados - kinta greitai, ịsiterpiant kitoms tendencijoms. Tokiu būdu nesukuriama pauzè, leidžianti stabtelèti ir apmąstyti savo vartojimo ịpročius ar identitetą, kurị kuriame per dèvimą aprangą. Kiekviena mada pasireiškia taip, tarsi ji norètų gyvuoti amžinai ${ }^{5}$, tai puikiai pasiteisina nepaliekant vietos pabaigai ịvardyti, o užpildant ją nauja pradžia, visada nuteikiančia tobulesnei savęs versijai.

\section{Pirmoji mados pabaigos teorija}

Tiriant vartojimo ịpročius ir besikeičiantị rūbo pozicionavimą, svarbu pastebèti, kad ìvairiais laikotarpiais iškilusios vartojimo krizès buvo sprendžiamos kardinaliai skirtingais būdais. Pasak filosofo Larso Svendseno, ìvairių ribojimų taikymas buvo ypač gajus nuo XIII a. iki XVII a., kai tam tikri drabužiai ir daiktai buvo rezervuoti tik aukštesnèms socialinėms klasėms ${ }^{6}$. Dèl šios priežasties drabužiai pavirto svarbiais socialinio luomo atspindžiais, sukurdami gana aiškius ịvairių objektų socialinès padèties kriterijus. Tuometinio žmogaus gyvenime egzistuojant religijai, pats vartojimas turejjo tam tikrą ribą, moralines nuostatas, vertybinę sistemą, tad nustatinèti, kokio vartojimo tipas jau peržengia ribas, buvo paprasčiau nei šiandieną, kai bet kuri pastaba apie galimą vartotojo galių peržengimą laikoma asmens laisvių suvaržymu.

4 Lars Svendsen, Fashion: A Philosophy, translated by John Irons (London: Reaction books, 2006), 149 .

5 Georg Simmel, Sociologija ir kultūros filosofija (Vilnius: Margi raštai, 2007), 376.

6 Svendsen, Fashion: A Philosophy, 37. 


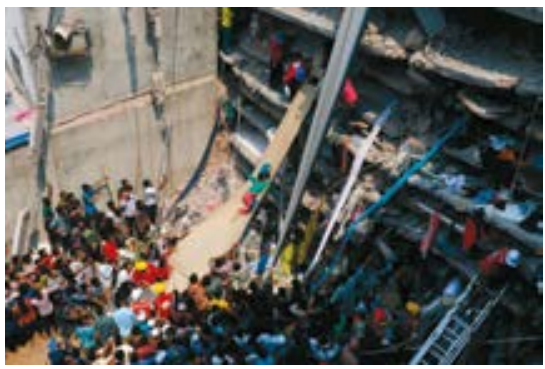

4.

Gamykla „Rana Plaza“ griūties metu, naudojant audinio rulonus, gelbejjamos tragedijos aukos, https://en.prothomalo.com/bangladesh/Fashionbrands-urged-to-pay-more-6yrs-after-Rana

During the collapse of Rana Plaza, the victims of the tragedy are rescued using fabric rolls

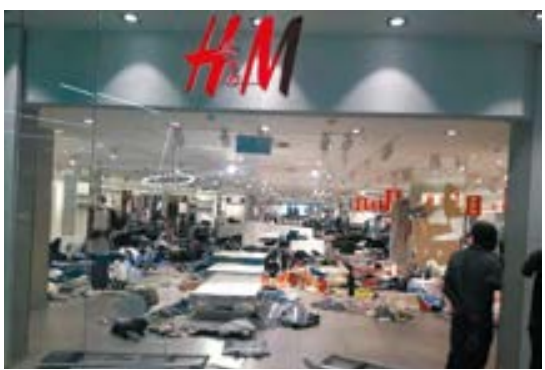

6.

Nusiaubta „H\&M“ parduotuvė Johanesburge, po protesto prieš rasistinę mados ženklo kampanija, https://www.nytimes.com/2018/01/13/world/africa/hmsouth-africa-protest.html

H\&M store in Johannesburg ravaged after a protest against a racist fashion brand campaign

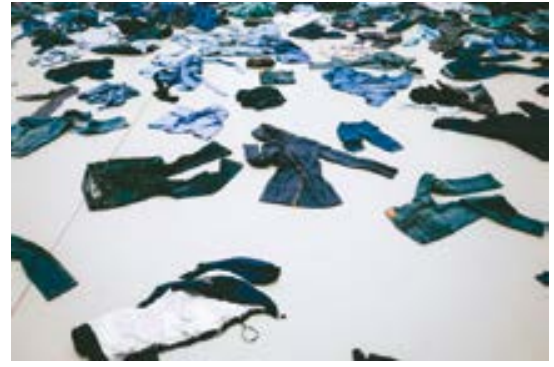

5.

Rūbų parduotuvės „Primark“ pardavimų salè per išpardavimus, https://www.reddit.com/r/CasualUK/ comments/98sks9/every_primark_floor_in_the country/

Clothing store Primark during sales

Nors kostiumo istorija ịvardijama kaip trukusi iki 1860 m., norisi i ši faktą pažvelgti kiek plačiau, stengiantis nusakyti bruožus, paklojusius pamatą šiam ịvykiui ịsigalèti. Nuo $1774 \mathrm{~m}$. Prancūziją pradèjo valdyti Liudvikas XVI, jo žmona Marija Antuanetė garsėjo išskirtiniu skoniu ir įnoringomis užgaidomis, kurias nuolankiai vykdè siuvejja Rose Bertin [7 il.]. Jų santykis ypatingas tuo, kad Bertin buvo pirmoji siuvejja, kuri pakluso klientui, vykdydama jo pageidavimus, o ne stengdamasi įteigti vyraujančias 
tendencijas. Rokoko laikotarpio rūbai gausiai dekoruoti, todèl labai brangūs, dèl to atsirado kostiumų nuoma, pasitarnavusi kaimo prasčiokams, atvykstantiems į miestą pasilinksminti. 1789-1794 m. vykusi Didžioji Prancūzijos revoliucija atnešė daug permainų. To meto dendžiai buvo pirmieji ịkūniję antimadą peržengdami savo laiko mados ribas, besiskelbiantys solipsistais, orientuotais ị save ir iššaukiančiai autonomiškais ${ }^{7}$. Jie rengėsi iki revoliucijos gyvavusios prabangios mados likučiais, būrèsi ị bohemiškas kompanijas, taip atrasdami naują stilių, kuris nebeatitiko to meto socialinių aktualijų. 1799 m. ịsigalejjus Napoleono Bonaparto valdymui, ypač skatintos mados užgaidos, idant jos stimuliuotų industrijos vystymąsi, pinigų apyvartą, padètų išbristi iš keblios to meto finansinès padèties. Buvo ịprasta, kad „paryžietè turi turèti tris šimtus šešiasdešimt penkis galvos apdangalus, tiek pat porų avalynès, šešis šimtus suknelių ir dvylika marškinių“8, tuo tarpu vyrai „savaitei turèti dvylika marškinių, dvidešimt keturias nosines, dešimt kelnių, trisdešimt skarelių, dvylika liemenių ir kojinių. “9 Aristokratija vertino atsipūtusio, bet stilingo žmogaus įvaizdį, todèl iš Anglijos atkeliavo mada sendinti rūbus, o paprasčiau - šie būdavo duodami kurị laiką panešioti tarnams. Po Prancūzijos revoliucijos, davusios pradžią pramonès vystymuisi, ịsigalèjo konfekcinė drabužių gamyba, vis daugiau moterų, ypač vyrų, pradejo rinktis gatavus drabužius:

\footnotetext{
Gamybos plètimasis priklausė nuo kapitalo apsisukimo greičio. Norint, kad greičiau būtų išperkamos prekès, reikėjo daug didesnės pasiūlos, gausesnio asortimento. Tai dar viena priežastis, dèl kurios mada XIX a. keičiasi daug greičiau. Anksčiau tam tikras periodas apimdavo 100 metų, o dabar $-10-15$ metų. ${ }^{10}$
}

1805 m. kilo finansinè krizè, po poros metų - pramoninė. Sugriuvus Napoleono imperijai, mada tapo labiau prieinama plačiajai visuomenei. İsigalëjus bydermejerio stiliui, pamėgdžiojant prabangą: „vietoj šilkinių sienų apmušalų gaminami popieriniai, odą pakeičia spaustas ir dažytas kartonas,

7 Adam Geczy ir Vicki Karaminas, „Walter Benjamin: Fashion, Modernity and the City Street“, in Agnès Rocamora ir Anneke Smelik, Thinking through Fashion. A Guide to Key Theorists (London: I. B. Tauris \& Co. Ltd, 2016), 85.

8 Rūta Guzevičiūtè, Europos kostiumo tūkstantmetis (X-Xa.) (Vilnius: Vaga, 2001), 9.

9 Ibid., 169.

10 Virginija Idzelytè, Kostiumo istorija (Vilnius: Vilniaus dailès akademijos leidykla, 2009), 269 . 


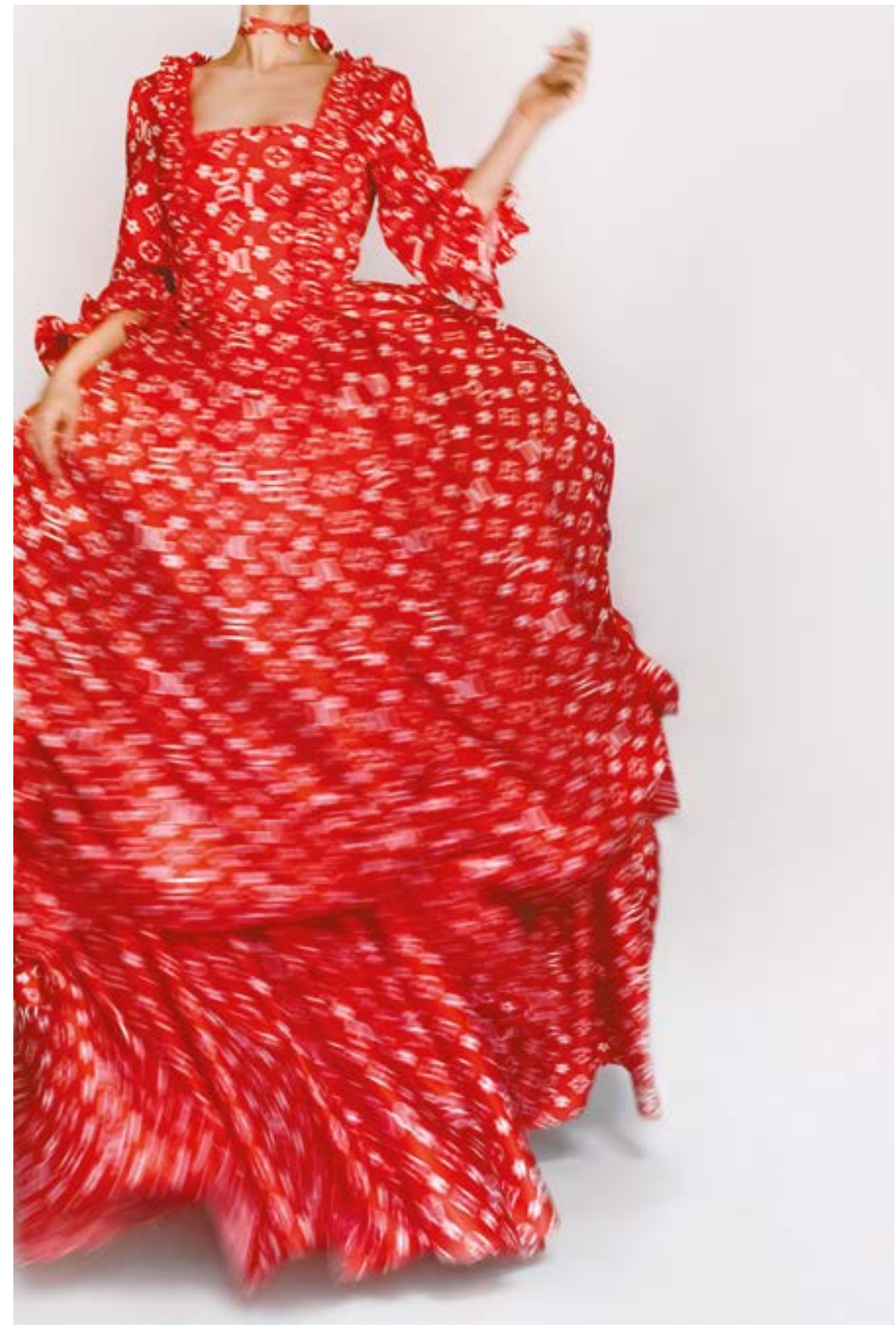

Liucija Kvašytė, Suknele Marijai Antuanetei, 2020, audinys, metalo konstrukcija, Vilnius, Rasos Baltrūnaitès nuotrauka
Liucija Kvašyte, Dress for Mary Antoinette, 2020 fabric, metal construction, Vilnius, photo by Rasa Baltrūnaitè 
mašina gaminti mezginiai tik primena senuosius, rankų darbo"11. Atsirado daugiaspalvès spausdinimo mašinos perrotina, audeklai tapo daug pigesni, ypač populiarūs tarp ne itin turtingų visuomenès narių. Pradèta dèvèti prisegamas apykakles, rankogalius, antkrūtinius. Visa tai skatino madingu prekių pasiūlą, susidarè „pasiekiamos prabangos“ iliuzija. Antrasis rokokas vienas labiausiai klestëjusių mados laikotarpių, nes per ši laiką nevyko nẻ vienas karas, o audinių pramonè klestėjo kaip niekad. Prabanga yra esminis dalykas, nebūtinai sutampantis su estetika arba išlavintu skoniu. Moderno laikas (1890-1914) pasižymėjo lygiụ teisių abiem lytims siekiu, tačiau to meto visuomenei tai dar buvo svetima: „Dienraštis Punch (Anglija) $1890 \mathrm{~m}$. išspausdino karikatūrą, vaizduojančią supanašèjusius vyrą ir moterị." ${ }^{12}$ Pradėjo kurtis mados namai, masiškai naudotos inžinieriaus Barthelémy Thimonnier sukurtos siuvimo mašinos. Tapo madingi audiniai su atspaustu raštu, nes juose derèjo ir tam laikotrapiui būdinga pigi prabanga, ir praktiškumas: margame audinyje nesimate dėmių ir audinio raštas puikiai paslèpė siuvimo defektus. Popierinius rūbų lekalus savamoksliškam siuvimui praktikuoti èmė publikuoti madų žurnalas World Fashion ${ }^{13}$.

Pirmieji rūbai, pagaminti pagal šiandien mums suprantamus standartinius išmatavimus, buvo pasitikti ịtūžusių miestiečių, šioje naujovėje j̇žiūrèjusių pasikėsinimą i i individualumą ir asmenybės laisvę: „Tu daugiau nebe žmogiškoji būtybė - tu tik aukštis ir plotis. "“14 Tačiau protestai greitai nurimo, nes žmonès jau nebenorèjo gaišti laiko ir mokèti ženkliai didesnes sumas pas kutiurjè (pranc. couturier). Turtingieji vèl galèjo džiaugtis išskirtiniu dèmesiu, o eiliniai miestiečiai - dideliu prekių pasirinkimu už prieinamą kainą. $1860 \mathrm{~m}$. dizaineris Frederikas Worthas atidarè saloną Paryžiuje ir ant gatavų savo kurtų rūbų pradèjo siūti etiketes - tai buvo neregètas to laikotarpio gestas: „Worth'o karjera paskatino mados dizainerio „emancipaciją“ nuo buvimo paprastu amatininku, visiškai priklausančiu nuo kliento norų, iki buvimo „laisvu kūrèju“.“"15 Tačiau galima pastebèti ir kitą to laikotarpio tendencija - populiarejjant plagijavimui, etiketè veikè kaip apsauga atsirenkant originalų daiktą nuo padirbinio, tačiau neilgai trukus ir ši saugikli buvo išmokta apeiti. Vis dèlto jo kurti rūbai buvo orientuoti i

11 Guzevičiūtè, Europos kostiumo tūkstantmetis (X-XXa.), 194.

12 Idzelytè, Kostiumo istorija, 315.

13 Guzevičiūtè, Europos kostiumo tūkstantmetis (X-XX a.), 193.

14 Ibid.

15 Svendsen, Fashion: A Philosophy, 90. 


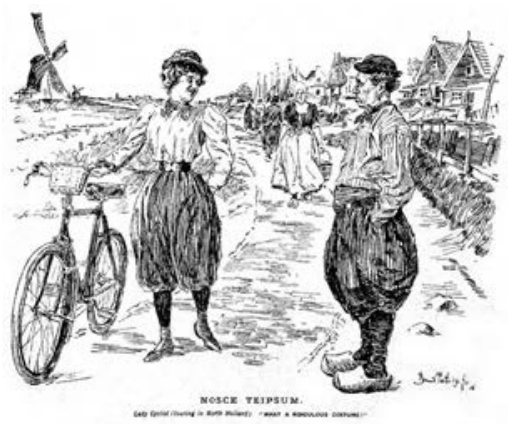

Karikatūra Nosce te Ipsum, „Punch magazine“, 1898, http://www.sheilahanlon. com/?p=270

Caricature Nosce te Ipsum, Punch magazine, 1898

aristokratišką gyvenimo būdą - teatrus ir vakarèlius, kurie nebebuvo aktualūs to meto veiklaus žmogaus gyvenime, todèl labiau primena šlovingu laikų mėgdžiojimą nei aktualijų ịprasminimą.

Moteriško kostiumo pasikeitimui nemažą įtaką turẻjo 1895 m. išrastas rentgeno aparatas, kuris parodė didelę korsetų žalą, gydytojai rekomendavo sumažinti rūbų svorị, vietoj daug pasijonių, šilumai palaikyti, dèvèti apatines kelnes. Vèliau moterų emancipacija suaktyvino jų poreikį užsiimti visuomenine veikla, sportuoti, labiau rūpintis sveikata. $1896 \mathrm{~m}$. ìvykusios pirmosios olimpinės žaidynės išpopuliarino asmeninị sportą, atsirado sporto rūbai, dviejų dalių kostiumai, skirti važinėti dviračiu [8 il.]. Pasikeitè patrauklios moters įvaizdis - ji tapo berniukiška, lengvai įdegusi, dėvinti paskutinès mados, socialinio aktyvisto ir tekstilininko Williamo Morisso pasiūlytą vientiso kirpimo suknelę, atitinkančią to meto emancipuotos moters įvaizdį.

1917 m., Pirmojo pasaulinio karo metu, Prancūzijos valdžia uždraudė nešioti vakarines sukneles ir brangenybes teatre. Išryškèjo amatiškumo aktualumas, moterys pačios siuvosi rūbus, persitvarkė senus apdarus pritaikydamos juos pasikeitusiam gyvenimo būdui. Žurnaluose atsirado patarimų skiltys - kaip iš seno sijono pasidaryti kelnes, iš senos užuolaidos pasisiūti „valstietišką“ sijoną ${ }^{16}$. Daugelis audinių buvo naudojami karo pramonėje, todèl paltai ir puspalčiai dažnai buvo siuvami iš apklotų ir pledų, madingomis tapo megztos vyriškos liemenės, kurių priekis buvo iš geresnių, o nugara - iš prastesnių siūlų.

1929 m. pirmą kartą pritaikyta ịsipareigojimo sistema tarp Europos dizainerių ir Amerikos verslo, kaip teisèta priemonė parduoti originalius 
europietiškus drabužius gamintojams ir mažmenininkams, kurie juos naudotų kaip dizaino šaltinius ${ }^{17}$. Nors iš pradžių toks susitarimas turẻjo populiarinti europietišką dizainą už Atlanto, greitai šis modelis išsigimè. Tuo metu Amerika turèjo geresnes masinès gamybos sąlygas, todèl „Dior“ ar „Balenciaga" mados namų gaminiai ten buvo pradèti gaminti dideliais kiekiais ir pasirodydavo rinkoje anksčiau nei pačiame Paryžiuje. Dėl tinkamai išvystytos gamybos grandinės gaminiai buvo pigesni, o laikui bėgant verslininkai pradėjo reikalauti, kad dizaineriai supaprastintų modelius, pavyzdžiui, atsisakytų sudètingos apykaklès konstrukcijos ar kišenių, ryškias spalvas keistų i subtilesnius atspalvius. Tačiau jau 1940 m., karo išvakarėse, daugelis europinių mados namų išsikèlè ị Ameriką. Čia lengvoji pramonė buvo išsivysčiusi, gaminti dideli kiekiai ịvairiausių audinių ir kitų kostiumų aksesuarų, vis dèlto garsėjo neilgalaikèmis, ekstravagantiškomis pasiūlomis, dažnai vienkartiniais ir pigiais daiktais ${ }^{18}$. Tačiau darbo ir sportinių drabužių srityje Amerika neturèjo konkurentų, o tai padejo jai pasiekti nemažų rezultatų drabužiu gamyboje vėlesniu laiku. 1941 m. Jungtinès Amerikos Valstijos, ìstojusios ị karą, išleido raštus, reglamentuojančius audinių naudojimą - uždrausta siūti plačius, kliošu kirptus sijonus. Anglijoje apribojimai buvo dar griežtesni - čia riboti ne tik audiniai, bet ir drabužių tipai; buvo sukurti 32 drabužių modeliai, kurie buvo atrinkti ir leista juos siūti masiškai. $1940 \mathrm{~m}$. pasirodė „Tiekimo apribojimo ịsakas“, kuris reglamentavo audinių kieki, galimą kostiumams siūti, todèl paltui tekdavo ne daugiau kaip 4 metrai audeklo. Atsirado kortelès viskozei - populiariausiam ir prieinamiausiam to meto audeklui. Daugelis ėmė persiųti drabužius namuose. Vadinamieji komplektiniai drabužiai, sukurti su Civilian Clothing 41 (civiliniai drabužiai) etikete, buvo gaminami siekiant palaikyti šalies ekonomiką ir orientuoti gyventojus ị ilgalaikį bei kokybišką produktą. Trūko audinių, todèl šilką ir vilną pakeitė viskozè, vilną pradèta maišyti su sintetika. Užtrauktukai buvo uždrausti taupant metalą, o gumos gauti buvo nepaprastai sunku, todèl to meto suknelès buvo siuvamos be elastinių diržų arba kitokių figūrą išryškinančiu detalių ${ }^{19}$. Apribotas kišenių kiekis, nustatytas didžiausias vyriškų marškinių ilgis ir uždraustas vyriškų kelnių palenkimas. Kiek įmanoma rūbai siūti iš

17 Alexander Palmer, Couture and Commerce: The Transatlantic Fashion Trade in the 1950s (Vancouver: University of British Columbia Press, 2001), 138.

18 Guzevičiūtè, Europos kostiumo tūkstantmetis ( $X-X X$ a.), 348 .

19 June Marsh, Mados istorija: nuo New Look iki šiandien, vertė Aistė Kvedaraitė-Nichols (Vilnius: Gimtasis žodis, 2012), 16. 
stačiakampių detalių, be raukinių, taip siekiant neprarasti nė centimetro sukerpant audinį. Šie apribojimai truko iki 1949 m. ir kèlè daug diskusijų apie tikraja „uniformos“ reikšmę - apriboti, sutelkti, paveikti.

1945 m. aukštosios mados sindikatas sugalvojo „Theatre de la Mode“ (mados teatras) - nauji drabužių modeliai buvo demonstruojami nedideliu $70 \mathrm{~cm}$ aukščio masteliu. Tai siejasi su XVIII a. paplitusiomis lèlèmis Pandora, kurios keliavo per pasauli kaip naujų mados vẻjų nešèjos ir populiarintojos. Tai padèjo Paryžiui aplenkti Ameriką ir vėl pirmauti tarp didžiausių mados sostinių ${ }^{20}$. Rinkoje atsirado gaminiai su užrašu etiketèje must have (būtina turèti), o pokario laikotarpiu (1945-1950) daugeliui ramybę reiškè sugrị̌imas prie komforto.

1947 m. dizaineris Christianas Dioras sukūrė New Look - naujajj ìvaizdị, tobulai atitikusị to meto moters etaloną. Tuo pačiu tai tarsi paskutinis bandymas visuomenei ịpiršti rūbą, kuriame dera meistrystė ir išmanymas, tačiau, kaip teigia mados istorikè Valerie Steele, „Mada „baigiasi“ po Dior New Look, kuris ne tik nustatė universalų standartą, bet ir buvo paskutinis visa apimantis stilius, fiziškai manipuliavęs kūnu““. Visgi vertinant iš šiandieninès perspektyvos, taip sėkmingai sutiktas Dioro modelis nuo pat savo pirmos egzistavimo dienos jau buvo retro rūbas, šlovinantis anuos laikus, kai moters etalonas buvo daili namų šeimininkè ir kai rūbui pasiūti buvo išnaudojami rulonai audinio ${ }^{22}$. Tai niekaip nebeatitiko ir to meto moters ịvaizdžio - emancipuota moteris, siekianti individualumo ir karjeros, visuomenei jau buvo pažistama su pirmaisiais dizainerès Coco Chanel trikotažo kostiumèliais, įdegiu ir tiesiais, figūros neišryškinančiais siluetais.

\section{Meno pabaiga pagal A. Danto}

Norint palyginti ši mados virsmą su meno lauko situacija, tenka grị̌ži ị XX a. pradžią, kai atsirado daugiau mados leidinių, reklamuojančių mados ir grožio industrijos prekes, o kinas tapo vis svarbesniu žmonių laiko leidimo būdu. Fotografijos, ypač kinematografijos, atsiradimas pakeitè tuo metu gajų mimetinị vaizdavimą, parodžiusị, kad tradicinès vaizduojamosios ar skulptūrinès laikmenos yra pasiekusios savo ribą ir atvėrusios kelią ekspresyvaus meno sampratai, buvo viena priežasčių, nulèmusių ir A. Danto

20 Idzelytè, Kostiumo istorija, 349.

21 Valerie Steele, „Fashion futures“, in Adam Geczy ir Vicki Karaminas, The End of Fashion: Clothing and Dress in the Age of Globalization (London: Bloomsbury, 2018), 3.

22 Svendsen, Fashion: A Philosophy, 29. 
Meno istorijos pabaiga, kurioje jis pristate meno sampratos istoriją. Jo teorijoje laikas skeliamas ị dvi dalis - iki $1960 \mathrm{~m}$. ir vèliau, kas akivaizdžiai sutapo ir su mados chronologine seka. Pokyčius autorius numatè jau amžiaus pradžioje pasaulyje, kuriame buvo juntama technologijų itaka žmogaus gyvenime. Postmodernizmo tendencijų išskirtinumui būdingas atkartojimas, tarpdiscipliniškumas, dėmesys konceptui ir kūrybos proceso sureikšminimas paties kūrinio atžvilgiu. XX a. pirmoje pusèje atsiradusios meno srovės nebepateisino ekspresyvumo poreikio. Tačiau ne visų meno kūrinių esminis komponentas yra ekspresija ir ji nebūtinai nusako meniškumą: „Jei teigtume, kad menininkas gali išreikšti vis daugiau ar vis subtilesnių jausmų, tai liudytų ne meno, o moralès, laisvès pažangą “233 Maždaug 1960 m. susiformavo abstraktusis ekspresionizmas, paskui kiti eklektiški judejjimai (fluxus, popartas, hiperrealizmas, akcijos, hepeningai, performansai), neturintys bendro principo ar ideologijos. Pasak autoriaus: „Tuo metu kūrybiškumas atrodè labiau susijęs su laikotarpio kūrimu nei su kūrinio kūrimu. ${ }^{\text {(24 }}$ To meto kūrẻjo ekspresija ir išmonè netruko peržengti ịsivaizduojamų iki tol vyravusio meno ribų, nes visos kryptys turẻjo absoliučiai naują požiūrị tiek i objekto kūrimą, tiek ị patị objektą:

Ekspresionizmo atsiradimu baigėsi tradicinė vaizduojamojo meno istorija, nes menininkai nebesistengė kurti tiesioginių juslinių ịspūdžių atitikmenų; nes ekspresionizmo ir vẻlesnių krypčių kūriniai sudarè tik individualių kūrinių seką, jie galèjo būti kuriami kita tvarka; nes skirtingos meno kryptys koegzistavo, o ne keitè viena kitą. $^{25}$

Tačiau esminis objektas, palietęs Arthuro Danto ir išprovokavęs meno pabaigos teoriją, buvo Andy Warholo eksponuota Brillo Box metaliniu kempinių dèžutè, tokia pati, kokią buvo galima rasti to meto prekybos centre, ir kurios naujos reikšmės kelia klausimą apie meno pobūdį ir atskleidžia filosofinę meno prigimtį. Iš to suprantama, kad meno esmè glūdi idèjose arba konceptuose, tiriama, kaip menas suvokiamas visuomenėje, kvestionuojami

23 Rūta Marija Vabalaitè, „Paradigminių meno pokyčių sampratos“, Logos 76 (Vilnius: Mykolo Romerio universitetas, 2013), 86.

24 Arthur Coleman Danto, The Philosophical Disenfranchisement of Art (New York: Columbia University Press, 1986), 108.

25 Rūta Marija Vabalaite, „Meno istorijos pabaiga“ A. Danto teorijoje“, Problemos 49 (Vilnius: Vilniaus universiteto leidykla, 1996), 165. 
dailès interpretacijos stereotipai, pasitelkus lingvistiką, filosofiją, sociologiją, meno kritiką arba kasdieninị patyrimą, analizuojamos meno idèjos, t. y. menas pats domisi savimi ir kelia analitinic klausimą apie save:

meno buvimas vis labiau priklauso nuo teorijos, taigi ji nėra kažkas išoriška pasauliui, kurị ji nori suprasti, o priešingai - suprasdama savo objektą, ji turi suprasti pati save. Kita šių vẻliausių kūrinių ypatybè ta, kad objektai artejja prie nulio, o jų teorija artėja ị begalybę, taigi faktiškai tai, kas lieka, yra teorija, menui galiausiai ištirpstant grynojo mąstymo apie ji pati spindesyje ir beliekant tik teorinès savimonès objektu. ${ }^{26}$

Tačiau kyla klausimas, ar kiekvienas daiktas, paremtas filosofine ideja, gali tapti meno kūriniu? A. Danto bando rasti visiems atvejams tinkamą meno apibrèžimą, vienas jų apibūdinamas tuo, kad kūriniai yra įkūnytos prasmės, interpretuojamos žiūrovo. Bet ar jam netenka pernelyg didelė privilegija nuspręsti, kad prieš ji esantis objektas yra meno kūrinys? Šis įterpinys, nušviečiantis tuometinio meno lauką, tampa tiltu ị mados procesus, prasidedančius iškart po meno pabaigos paskelbimo ir avangardo pradžios mados dizainerių kūryboje. Apžvelgiant mados lauką, visų pirma reikètų išsiaiškinti: ką reiškia drabužis? Tokị klausimą kẻlė mados dizaineriai, kūrę 1960-1990 m. ir bandę sugrąžinti madą ị kultūros lauką. Pasak Svendsen, galima būtų teigti, kad drabužis reiškia tai, ką per jị ketino pasakyti dizaineris. Tačiau šis požiūris yra problemiškas, nes menininkas nèra privilegijuotas, kaip ilgą laiką buvo teigiama, ir jis nèra viršesnis ar teisingesnis, kai reikia suprasti savo kūrinị: „Menininkas yra tiesiog vertėjas, lygiavertis visiems kitiems vertėjams. " ${ }^{27}$ Taigi būtų galima numanyti, kad tiek kūrèjas, tiek vartotojas neatsiejamai kuria naujas objekto prasmes.

\section{Meno ir mados santykis}

Mada visada norejjo priklausyti meno laukui, tačiau klausimas, ar mada yra menas, vis dar lieka diskutuotinu. Siekis igauti meno statusą ypač išryškėjo nuo 1960 m., kai besivystanti mada tapo priemone identitetui formuotis. Dèl politinių ir socialinių pokyčių ji vis alternatyvejjo ir vis labiau 


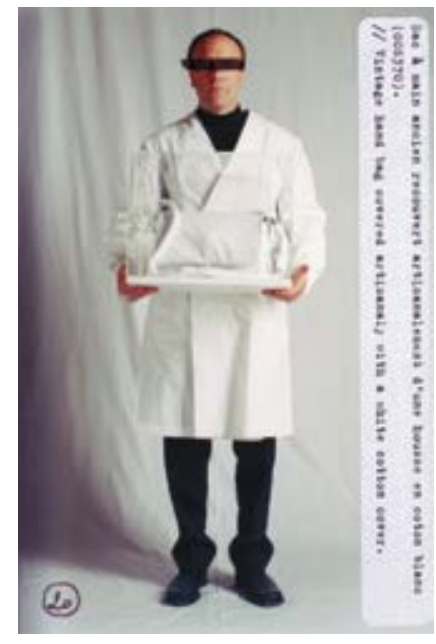

\author{
9. \\ Dizainerio Martino Margielos \\ kūrybos pristatymai išsiskiria \\ neịprastu pateikimu, kvestionuojant \\ mados ir meno santykị, https:// \\ www.wallpaper.com/fashion/martin- \\ margiela-exhibition-antwerp \\ The fashion shows of the designer \\ Martin Margiela are distinguished by \\ an unusual presentation, questioning \\ the relationship between fashion \\ and art
}

grę̨žėsi ị žmogų. Rūbas tapo ịrankiu reikšti nuomonę, priklausyti socialinėms grupėms ar subkultūroms. Kaip teigia meno kritikas Nicolas Bourriaud: „popmeno ikonografija nurodo vartojimo erą, ypač prekybos centro išvaizdą ir su juo susijusias naujas rinkodaros formas: vizualinị frontalumą, serijiškumą, gausą. “"28 Augantis kapitalizmas dažnai buvo būdu pasipriešinti, taikyti nestandartinius sprendimus. Seksualinės revoliucijos metu buvo pasiūlyti „labai maži“ rūbai, sukèlę pasipiktinimą tarp pramoninkų, mat tokiems drabužiams reikia labai nedaug audinio ir gamyba nèra naši ${ }^{29}$. Vivienne Westwood, pasisavinusi pankų subkultūros anarchistiškumą ir destruktyvumą, pristatė kolekciją, kurioje apatiniai drabužiai tapo viršutiniais. Marilyn Newman sukūrė pirmuosius unisex modelius, o „po 1967-uјjų reformos, kuri išteisino savanorišką seksualinį aktą tarp dviejų vyresnių nei dvidešimt vienų metų vyrų, smarkiai pakilo vyrų domejjimasis mada.“30

Nors daugeliu atvejų mada yra elementari rūbų gamybos sritis, netrūksta ir pavyzdžių, rodančių, kad, kaip ir menininkai, savo kuriamais objektais dizaineriai pristato filosofines idejjas, leidžiančias kūrini prilyginti meno objektui. Mados istorikė Natalie Khan teigia, kad dizainerio Martino Margielos kūriama mada yra meno kūriniai, o ne dizainas, todèl, kad juose pateikiamas refleksyvus komentaras apie tikrają mados industriją, kurios dalis jis pats yra [9 il.]. Dizaineris nevengè priešintis nusistovẻjusioms

28 Nicolas Bourriaud, Postproduction Culture as Screenplay: How Art Reprograms the World (New York: Lukas \& Sternberg, 2002), 85.

29 Idzelytè, Kostiumo istorija, 327.

30 Marsh, Mados istorija: nuo New Look iki šiandien, 106. 
mados pramonės taisyklèms perkurdamas arba iš naujo pristatydamas senus darbus ${ }^{31}$. Pasak teoretiko Clemento Greenbergo, modernizmo esmè yra tai, kad kiekvienas menas turi ịrodyti savo išskirtinị identitetą, kas jam būdinga, kad pabrèžtų jo absoliučią autonomiją ${ }^{32}$. Kiekviena meno disciplina turi gebėti kritiškai pažvelgti ị save, kad galètų atskirti esminius dalykus apie šią discipliną, kad jie priartètų prie savo būties suvokimo. Svendsenas duoda pavyzdi apie 6 deš. vykusią meno ir mados sintezę, ivvardydamas: „popmenas ir mada yra sukurti vienas kitam. “"33 Omenyje jis turi tokias koloboracijas, kaip 1965 m. Yves'o Saint-Laurent'o sukurtą kolekciją, įkvèptą Pieto Mondriano, Andy Warholo pasiūtą popierinę suknelę ir Cindy Sherman darbe United Nr. 131 dèvimą Jeano Paulo Gaultier korsetą. Bet ar meno, kaip inspiracijos, naudojimas padaro objektą menu? Šiai sintezei apibūdinti labiau tinkamu laikyčiau meno teoretiko ir kritiko Virginijaus Kinčinaičio „kontrabandos būdo“ taikymą ${ }^{34}$, kai iš menininko „pasiskolinama“ patikusi detalè ar motyvas ir interpretuojama bandant perimti skolinio vertes, kurių pats daiktas neturi. Pavyzdžiui, prancūzų dizaineris Saint-Laurent'as savo kolekcijoje panaudojo olandų tapytojo Mondriano paveikslą Composition with Yellow, Red, Black, Blue, and Gray (1920) ji perkeldamas ant tuo metu (1965) tipiškos A silueto suknelès. Kaip paaiškèjo vèliau, tai jau buvo padarę dizaineriai Michèle Rosier ir Johnas Klossas, bet dèl Yves'o Saint-Laurent'o populiarumo, būtent jo kurtos suknelès mums visų pirma asocijuojasi su Pieto Mondriano kūryba.

Kompleksuotos mados troškimas igyti meno statusą negali būti pasiektas, nes jame pernelyg orientuojamasi į masinę gamybą. Kaip viename interviu teigė Bourriaud: „Menas yra priešprieša masiškumui. Norèdamas kurti vienetines vertybes, turi laikytis atokiau nuo masinio gaminimo mašinos. " ${ }^{35}$

Apie 1980-uosius iškilo konceptualios mados banga, kuriai atstovavo tokie dizaineriai kaip Rei Kawakubo, Martinas Margiela, Helmutas

31 Svendsen, Fashion: A Philosophy, 32.

32 Ibid., 106.

33 Ibid., 96.

34 Virginijus Kinčinaitis, „Mados dinamika mene“, 2020, https://www.facebook.com/watch/ live/?v=369814720787292\&ref=watch_permalink.

35 Mindaugas Klusas, „Mano pasaulyje žmogus niekada nėra vienišas“, pokalbis su Nicolas Bourriaud, 2012, https:/www.7md.lt/tarp_disciplinu/2012-11-16/Mano-pasaulyje-zmogus-niekadanera-vienisas. 
Langas, Jeanas Paulis Gaultier ir kiti. Jų kuriama mada oponavo tuo metu vyravusiai plastikiniu ir sintetiniu mados tendencijų problematikai:

Daugelis drabužių buvo sukurti su išverstomis siūlemis, ir tai galima palyginti su modernaus meno tendencija pabrèžti kūrinio medžiagiškumą, pavyzdžiui, paveiksluose aiškiai paliekant pieštuko linijas. Devintajame dešimtmetyje Rei Kawakubo pradėjo kurti audinius, turinčius „,trūkumų“, „,sabotuodama“ juos gaminančias mašinas, po to leisdama audiniams keletą dienų būti veikiamiems vèjo ir oro. ${ }^{36}$

Tokiu būdu dizaineriai stengèsi ị madą grąžinti amatą, medžiagiškumą ir meistrystę, savitą estetiką be populiariosios kultūros priemaišų.

Šiandieninės mados dizainerių kūryboje mados pabaiga pasireiškia kaip neatitikimas greitosios mados normoms. Pradedant mados savaičių atsisakymu, pereinant i netradicinę ekspozicijos ar performanso raišką, kuriant dèvèjimui netinkamus rūbus ar objektus, kurie paneigia mados pramonės suprojektuotą greitị ir tuštybę [10 il.]. Daugiau dèmesio skiriama idejjinei rūbo pusei, akcentuojama mados lauko kritika, jos vizualinis poveikis, o ne funkcionalumas ar atitiktis masiniam skoniui. Tokių dizainerių kūryba išsiskiria mados kontekste ir atrodo kitoniška, kalbanti drąsiau ir pasitelkianti alternatyvesnes idėjas. Deja, meno kontekste konceptualiausias mados objektas dažnai nėra vertas net meno kūrinio statuso. Todèl pasak Suzy Menkes, „kad rūbas būtų mada, jis turi būti dèvimas“37, bet, jei jis paremtas dar ir konceptualia teorija, jị būtų galima vadinti taikomuoju menu. Tačiau tai tik išimtys.

\section{Fast fashion ir antroji mados pabaiga}

9 deš. kūrèsi mados superkompanijos, o dizainerių vardai tapo prekiniais ženklais ${ }^{38}$. Haute couture kolekcijų pristatymai sausakimši, bilietai i juos kainavo po 600 JAV dolerių. Aukštoji mada tapo pramogu pasaulio dalimi, dizaineriai kūrè sukneles ir kitus apdarus apdovanojimams ir vakarèliams. Iki šiol tokių rūbų gamyba nẻra pelningas verslas, tačiau pagrindinis kapitalas uždirbamas iš reklamos ir kuriamo prestižo. $1987 \mathrm{~m}$. įvyko „Juodojo pirmadienio“ krizè, suiro SSRS, nugriauta Berlyno siena.

36 Svendsen, Fashion: A Philosophy, 91.

37 Ibid., 104.

38 Marsh, Mados istorija: nuo New Look iki šiandien, 156. 


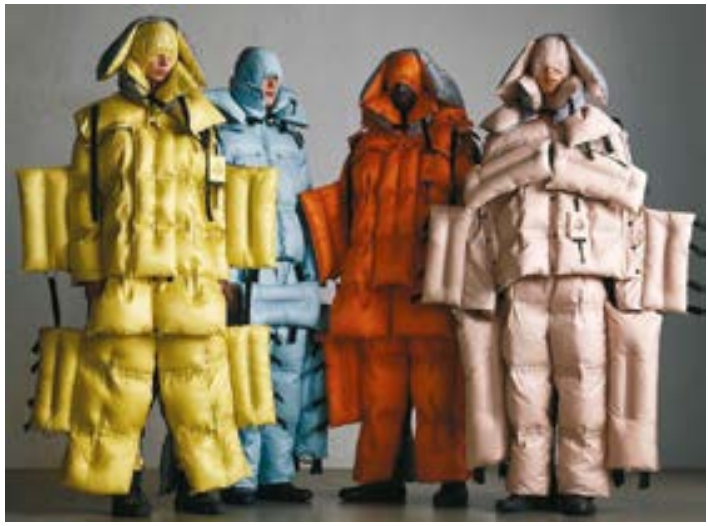

10.

Dizainerio Craigo Greeno bendradarbiavimas su mados ženklu „Moncler“, https:// www.dazeddigital.com/fashion/ article/43454/1/craig-greenmoncler-genius-aw19-mfw-milanfashion-week

Designer Craig Green's collaboration with the fashion brand Moncler

Nemažai Europos vyrų dizainerių susirgo AIDS, todèl investuotojai nuo jų nusigręžè, ir mados pasaulis apsivertè aukštyn kojomis. Išpopuliarèjo antimadą propaguojantis grunge stilius, per purvinus, nusivėlusius ir suplyšusius rūbus demonstruojantis nihilizmą, destrukciją ir neužtikrintą ateiti. Kaip opozicija 9 deš. pilkumai ir nykumui, 10 deš. iškilusios masinès rinkos mados tendencijos igavo tiesioginę įtaką prabangių prekių gamybos sektoriui. Masinès mados rinka sparčiai augo dèl tobulejjančių ir pingančių gamybos technologijų, pranašesnio dizaino ir dinamiškesnių pardavimo alternatyvų. Tokios kompanijos kaip „Zara“ iš Ispanijos, „H\&M“ iš Švedijos ir „TopShop“ iš Didžiosios Britanijos pradejo gaminti aukštosios mados drabužius už prieinamą kainą ir pasiūlè pirkèjams prabangos prekių alternatyvų ne tik pigiau, bet ir greičiau, pristatę jas ant podiumų ${ }^{39}$.

Išsikreipęs gamybos modelis, perteklinis resursų naudojimas, žmogaus darbo jègos nevertinimas atvedè prie antrosios mados pabaigos teorijos, kurią iškèlè sociologijos profesorè Patrizia Calefato:

Teiginio „mados pabaiga“ pagrịstumas remiasi keturiais esminiais įvykiais. Pirma, mados sistemos gamybos, komunikacijos ir vartojimo būdai bei iš to išplaukiantis mados ir laiko santykis, pasklidus internetui ir skaitmeninėms laikmenoms. Antra, jau minèta sienų tarp globalios ir vietinès rinkos griūtis. Trečia, didejjantis mados ir meno perskirstymas. Ir ketvirta, žlungantis ir augantis nestabilumas, susijęs su rūbo, kaip identiteto, idèja. ${ }^{40}$ 
Dèl milžiniškos paklausos šiandien aprangos, avalynès ir tekstilès sektorius yra ryški ekonominè jèga, penktas pagal didumą, kurio vertė siekia 1,5 tūkst. mlrd. JAV dolerių ${ }^{41}$. Panašu, kad mados industrijos daroma žala buvo susirūpinta pavėluotai - ilgą laiką ji buvo atmesta kaip nesvarbus žmogaus veiklos aspektas, vien tik pramoginio pobūdžio, paviršutiniškumo, lengvabūdiškumo ir tuštybės pavyzdys, todèl laikyta menku žaidèju globalaus pasaulio arenoje $\mathrm{e}^{42}$. Niekas rimtu nepalaikè ir "The Triangle Shirtwaist“ gamyklos gaisro 1911 m., kurio pasekmè - visus pribloškusi „Rana Plaza“ gamyklos griūtis 2013 metais. Šioms, atrodo, nesusijusioms, tačiau labai panašioms katastrofoms apibūdinti tinka Mary Shelley pastebėjimas, kad lemtingi pokyčiai - pabaigos pradžia jau prasidejo, tačiau jie bus ịsisąmoninti tik tada, kai iš pradinės paslèptos fazės pereis ị paskutiniają pabaigos fazę, t. y. tada, kai iš esmès pasaulio irimo procesai jau bus negrịžtami ir neatšaukiami ${ }^{43}$. Tačiau būtent mada, būdama artima žmogaus ịvaizdžio, charakterio ir išraiškos kūrimo forma, per neilgą laiką sugebẻjo įkūnyti visus globalinės santvarkos bruožus ir pajungti visuomenę besaikiam vartojimui. Šiandien mados prekių vartojimas laikomas ne tik kaip tam tikro pajègumo ịpirkti arba būti kažko dalimi ịvaizdis, bet ir yra tapatinamas su laisva kūrybine individo raiška - pasirinkimo laisve ${ }^{44}$. Tai laikoma kūrybiniu darbu, nes pasiūla pernelyg didelè, o nuspręsti teisingai gali tik vartojimo kontekste „ıšsilavinęs“ žmogus. Deja, tai retai siejama su istorinio kostiumo ir mados išmanymu, savo kūno supratimu arba vidinio išskirtinumo puoselèjimu. Greičiau tai labai susiję su opia šiandienos problema, kai talentas ir meistriškumas atmetamas imituojant kūrejją.

Šiais laikais, nykstant vertybiniam pamatui, vartotojų bendruomenės buriasi i grupes, kurias sieja tam tikri pirkimo ir vartojimo ịpročiai. Vienu metu galima priklausyti daugeliui skirtingu grupių, taip neịsipareigojant, neprisiimant atsakomybės, o priklausymą išreiškiant per logotipus. Jie yra svarbūs prekiniams ženklams, nes jie gali padaryti juos akimirksniu atpažistamus pasauliui, o jų dèvèjimas gali reikšti, kad dèvètojas nori būti susietas su prekės ženklu ir prekės ženklo ideologija bei ịvaizdžiu,

41 M. Shahbandeh, „U.S. Apparel Market - Statistics \& Facts“, 2020, https://www.statista. com/topics/965/apparel-market-in-the-us/.

42 Hilary Radner, „Cinema“, in Geczy ir Karaminas, The End of Fashion, 85.

43 Nerijus Milerius, Apokalipsè kine: filosofinès prielaidos (Vilnius: Vilniaus universiteto leidykla, 2013), 147.

44 Vytautas Rubavičius, Postmodernusis kapitalizmas (Vilnius: Kitos knygos, 2010), 101. 
pavyzdžiui, reprezentuojamu gyvenimo būdu, vaizduojamu prekės ženklo rinkodaroje ir gaminiuose ${ }^{45}$. Prekinis ženklas „Supreme“ ugdo agresyvu atotrūkį, t. y. savo klientams sąmoningai kuria jausmą, kad jie nèra pakankamai „kieti“ igyti šio prekès ženklo gaminius. Šis prekės ženklas siekia, kad potencialūs vartotojai stengtųsi pasidaryti „kietais“, o ne iš karto įsigytų trokštamą prekę. Ši manipuliuojanti rinkodara yra protinga, nes žmogui labiau patinka pats siekio procesas nei faktas, kad igijo trokštamą daiktą. Jų strategija skatina nuolat dirbti, kol virstama pakankamai tinkamu būti šio prekės ženklo dalimi ${ }^{46}$. Dèl šios priežasties dažnu atveju i prekę nebežiūrima kaip ị objektą, naudingą ir įdomų dèl jo paties savybių, o orientuojamasi ị jo simbolinị turinį ${ }^{47}$ [11 il.]. Štai kodèl Nerijaus Mileriaus žodžiais, „perkant pagalvę, perkama ne pagalvè, o „dieviška ramybe்“, perkant dantų pastą - „neprilygstama gaiva“, kavą - „rojaus aromatas“ ar „,velniška aistra“, šokoladą - „gundanti nuodėmè“, jogurtą - „rytinė palaima“48. Mados rinka, siekdama sužadinti norą vartoti, niekada neleidžia žmogui jaustis iki galo tobulam ar „pasotintam“, todèl vyksta nenutrūkstanti gamybos grandinè, o kai jos prekè atsiduria pas visus vartotojus, ji tuojau praranda savo esmę - išskirtinumą ir ją pakeičia nauja prekè, vaidinanti tą patị deficitinị vaidmenį ${ }^{49}$.

\section{Teorijų panašumai ir problematika}

Apžvelgus pabaigos teorijas, išryškèja bendri dalykai - apie $1960 \mathrm{~m}$. atsiranda takoskyra tarp buvusio ir naujojo mąstymo; dideja technologiju itaka; aktualus tampa konceptualumas kaip bruožas, nusakantis objekto meniškumą. Čia nesigilinsime ị meno chronologiją, tačiau pakankamai akivaizdu, kad ir menas nebeliko toks pat, kokiu buvo vadinamas iki 6 deš., o mada pasikeitè (tebūnie ji būna tiesiog mada, o ne meno rūšis). Šiuo atveju menui šis lūžis atrodo daug natūralesnis nei mados laukui dèl kelių priežasčių.

Visų pirma mada visada norejjo atitikti to meto grožio standartus. Iki XIX a. juos diktavo aristokratija, nuo 1860 m. - kutiurjè, o nuo 1960-uju dizaineris. Šiandien ši privilegija atitekusi gatvès kultūrai, vadinasi, kiekvienam iš mūsų, vartojančiam mados pramonès kuriamas prekes. Tačiau

45 Carolyn Mair, The Psychology of Fashion (New York: Routledge, 2018), 70.

46 Ibid., 72.

47 Rubavičius, Postmodernusis kapitalizmas, 109.

48 Milerius, Apokalipsè kine: filosofinès prielaidos, 31.

49 Guy Debord, Spektaklio visuomene (Vilnius: Kitos knygos, 2006), 78. 


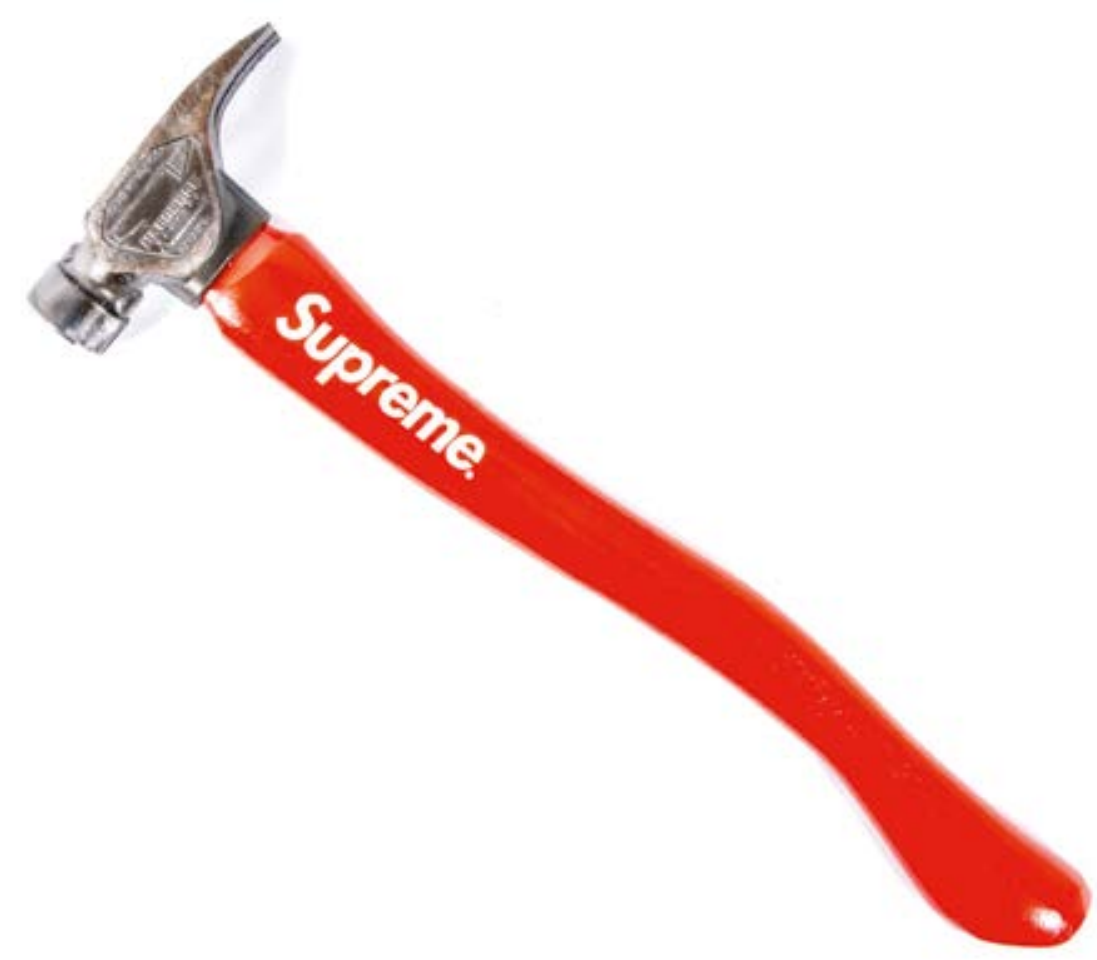

11.

Mados prekès ženklas „Supreme“ prekiauja ne tik mados objektais, bet ir îvairaus tipo gaminiais, ženklintais jų logotipu, www.sothebys.com/en/buy/ auction/2019/the-supreme-vault-1998-2018/supremehardcore-hammer
The fashion brand Supreme sells not only fashion objects, but also various types of products marked with their logo

didžiausi grožio standarto formuotojai šiandien žinomi kaip nuomonès formuotojai (influenceriai), kuriuos matome per televiziją, socialines medijas ir t. t. Jų kasdienybè, laisvo laiko leidimas ir jame egzistuojantys objektai šiandien formuoja grožio sampratą. Ir tai net nebūtinai žmonès, pažistami iš spaudos, Holivudo ar reklamų, tai gali būti net robotai, kuriais šiandien labiau pasitikima nei garsia moterimi savo socialineje paskyroje atstovaujančia penkioms kosmetikos kompanijoms. 
Antra, mada visada buvo orientuota ị masinę gamybą, nesvarbu, kokią reikšmę ji turèjo to meto situacijoje. Jos siekis buvo užimti kuo didesnes teritorijas ir savo kuriama produkcija aprūpinti kuo daugiau žmonių. Dèl šios priežasties siūloma mados egzistavimo šimtmeti pratęsti, t. y. mados pradžia laikyti ne 1860 m., o laikotarpi nuo XVIII a., kai išpopuliarėjo lèlès Pandora, davusios kelią pasaulinei mados sklaidai, kuri laikui bėgant transformavosi ir sklido per porcelianines lèles, iliustruotus madų žurnalus, kiek vèliau lèles Barbie, o šiandien per pačių moterų kūnus. Jau tada lèlès Pandora buvo siunčiamos i visas Europos šalis kaip etalonai, pagal kuriuos klientai galëjo užsisakyti norimą suknelès modeli. Net karo metu jos keliavo per pasienius be jokios kontrolès, nes buvo tikima, kad mada visada bus viena geriausių ekonomiką skatinančių priežasčių.

Galiausiai mada niekada nesulaukè rimtos kritikos dèl pernelyg susijusių rinkos sluoksnių ${ }^{50}$. Šiandieniniai mados žurnalai pilni reklamų tiesioginių ir manipuliatyvių, pavyzdžiui, straipsnis apie kūrèją, kuriuo reklamuojamas jo mados ženklas, arba renginio nuotraukos, po kuriomis pažymima, ką dèvi viena ar kita superžvaigždè. Tai yra taip smarkiai susiję ir susitapatinę su mūsų kasdiene kultūra, kad šiandien pasakyti žmogui, jog jis vartoja kompulsyviai, nesilaiko etikos normų ir pan., reiškia atimti iš jo laisvę ị identiteto formavimą. Verta prisiminti citatą, minètą teksto pradžioje, kai didmeninė gamyba tapo masiškai plintanti tarp XIV a. visuomenès: „Tu daugiau nebe žmogiškoji būtybė - tu tik aukštis ir plotis.“ Taigi asmeninès laisvès suvaržymas arba už pažeidimus taikomi apribojimai negali būti taikomi, nes taip pažeidžiamos žmogaus teisès. Kaip pasakytų Vytautas Rubavičius, „žmogus yra tapęs dievu, nes tikrajị Dievą iš savo gyvenimo jis jau seniai išvarè. “51

Vadinasi, mados kontekste kalbèti apie jos pabaigą, atrodo, vis dar yra neįmanoma, nes tuo drumsčiamas žmogaus mėgavimasis vartojimu ir, kaip minèta aukščiau, visa mados industrijoje dirbančių žmonių įtaka yra taip smarkiai susijusi ir persipynusi, kad šią temą bus nuolatos bandoma užtildyti neleidžiant jai skatinti žmonių sąmoningumo vartojant madą.

Taigi apžvelgę mados tyrëjų ir A. Danto pabaigos teorijas, matome, kad tiek mados, tiek meno laukas vystèsi panašia kryptimi, tačiau mada 
dèl savo noro atitikti tam tikro laikmečio grožio standartus, susikrauti kuo didesnị kapitalą ir dèl kritikos mados lauke nebuvimo spejo tiek pasikeisti, jog jos padariniai jau negrižtami ir pabaiga ne menama, o reali juntama fiziškai jau šiandien, bet apie ją vengiama kalbèti dèl pernelyg mūsų kasdienybejje ịsitvirtinusio mados vartotojiškumo. Tačiau pabaigos teorijos turi egzistuoti kaip svarbus atspirties taškas permąstant savo, kaip kūrèjo ir vartotojo, veiklos priežastis ir padarinius.

Gauta 20201218 


\section{Literatūra}

Baudrillard, Jean. Vartotoju visuomene: mitai ir struktūros. Kaunas: Kitos knygos, 2010.

Black, Sandy. The Sustainable Fashion Handbook. London: Thames \& Hudson, 2012.

Bourriaud, Nicolas. Postproduction Culture as Screenplay: How Art Reprograms the World. New York: Lukas \& Sternberg, 2002.

Danto, Arthur Coleman. The Philosophical Disenfranchisement of Art, [s.l.]. 1986.

Debord, Guy. Spektaklio visuomene. Vilnius: Kitos knygos, 2006.

Geczy Adam and Karaminas Vicki. The End of Fashion: Clothing and Dress in the Age of Globalization. London: Bloomsbury, 2018.

Guzevičiūtè, Rūta. Europos kostiumo tūkstantmetis ( $X-X X$ a.). Vilnius: Vaga, 2001.

Idzelytè, Virginija. Kostiumo istorija. Vilnius: Vilniaus dailès akademijos leidykla, 2008.

Kinčinaitis, Virginijus. „Mados dinamika mene“. 2020, žiūrèta 20201126 d.

<https://www.facebook.com/watch/li$\mathrm{ve} / \mathrm{v}=369814720787292 \& \mathrm{ref}=$ watch_permalink $>$.

Klusas, Mindaugas. „Mano pasaulyje žmogus niekada nèra vienišas", pokalbis su Nicolas Bourriaud, 7 Meno dienos, 2012.

$<$ https://www.7md.lt/tarp_disciplinu/2012-11-16/Mano-pasaulyje-zmogus-niekada-nera-vienisas $>$.

Mair, Carolyn. The Psychology of Fashion. New York: Routledge, 2018.

Marsh, June. Mados istorija: nuo New Look iki šiandien. Iš anglų kalbos vertè Aistė Kvedaraitė-Nichols. Vilnius: Gimtasis žodis, 2012.

Milerius, Nerijus. Apokalipsè kine: filosofiness prielaidos. Vilnius: Vilniaus universiteto leidykla, 2013.

Palmer, Alexandra. Couture and Commerce: The Transatlantic Fashion Trade in the 1950s. Canada: University of British Columbia Press, 2001.

Rocamora, Agnès and Anneke Smelik. Thinking through Fashion. A Guide to Key Theorists. London: I. B. Tauris \& Co. Ltd,
2016.

Rubavičius, Vytautas. Postmodernusis kapitalizmas. Vilnius: Kitos knygos, 2010.

Shahbandeh, M. „U.S. Apparel Market - Statistics \& Facts“. 2020.

$<$ https://www.statista.com/topics/965/apparelmarket-in-the-us/>.

Simmel, George. Sociologija ir kultūros filosofija. Vilnius: Margi raštai, 2007.

Svendsen, Lars. Fashion: A Philosophy, translated by John Irons. London: Reaktion books, 2006.

Vabalaitè, Rūta Marija. „Paradigminių meno pokyčių sampratos“. Logos. Vilnius: Mykolo Romerio universitetas, 2013.

__. „Meno istorijos pabaiga“ A. Danto teorijoje“. Problemos. Vilnius: Vilniaus universiteto leidykla, 1996. 


\title{
Summary
}

\section{The End Theories in the Fashion and Art Discourse}

\author{
Liucija Kvašytè
}

Keywords: end of fashion, end of art, fast fashion, history of costume.

The author of the text aims to stress the importance of different stages of fashion and brings out the "end" problematics in the field of fashion and art. The discussion of the development of fashion starts from the prehistory of the phenomenon of popular fashion as a recurring fashion cycle trend, which is untypically related to the rococo period and the era of the fashion influencer Marie Antoinette in 1772 instead of 1860, when the couturier F. Ch. Worth started working, thus seeking to assess the circumstances that created the preconditions for the appearance of the fashion market. The author identifies the ends that happened from the late 18th century to our days, separately distinguishing the End of Fashion by the fashion historian Valerie Steele in 1960, which coincides with the chronology offered by the philosopher Arthur Coleman Danto, and the ongoing second end of fashion, which was identified by the sociologist Patrizia Calefato. The author aims to pinpoint the inner operating principle of fashion, which is not based on the aim to improve, but produces a growing wish to consume more and to relate one's identity to material welfare. The article contains a brief overview of the highs and lows of fashion consumption, which were affected by social and cultural changes and shaped not only the special features of clothes, but also consumer needs. The author starts a discussion about the synthesis of art and fashion, asking what values are missing in today's fashion market, and what it should offer to the consumer or what the consumer should demand from it. Thus, the text aims to show the importance of the end theories as a means of constant rethinking of our relation to fashion, thus encouraging the awareness of designers and consumers regarding the issue of creative fashion and consumption.

$103-2021$

Acta Academiae Artium Vilnensis 